\title{
The environmental impact of lightweight HCPV modules: efficient design and effective deployment
}

\author{
Philip Sandwell ${ }^{1}$, Geoffrey Duggan², Jenny Nelson ${ }^{1}$ and Ned Ekins-Daukes ${ }^{1}$ \\ 1. Grantham Institute - Climate Change and the Environment and Department of \\ Physics, Imperial College London, London SW7 2AZ \\ 2. Fullsun Photovoltaics Limited, Shipley, West Yorkshire, BD18 3LA
}

\section{Abstract}

We present a life cycle analysis of a lightweight design of high concentration photovoltaic module. The materials and processes used in construction are considered to assess the total environmental impact of the module construction in terms of the cumulative energy demand and embodied greenhouse gas emissions, which were found to be $355.3 \mathrm{MJ}$ and 27.9 $\mathrm{kgCO}_{2 \text { eq }}$ respectively. We consider six potential deployment locations and the system energy payback times are calculated to be $0.22-0.33$ years whilst the greenhouse gas payback times are 0.29-0.88 years. The emissions intensities over the lifetimes of the systems are found to be 6.5-9.8 $\mathrm{g} \mathrm{CO}_{2 \mathrm{eq}} / \mathrm{kWh}$, lower than those of other HCPV, PV and CSP technologies in similar locations.

\section{Table of Contents}

The environmental impact of lightweight HCPV modules: efficient design and effective deployment......................................................... 1 Philip Sandwell', Geoffrey Duggan ${ }^{2}$, Jenny Nelson ${ }^{1}$ and Ned Ekins-Daukes ${ }^{1} .1$

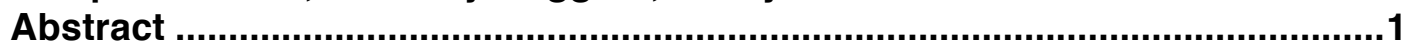

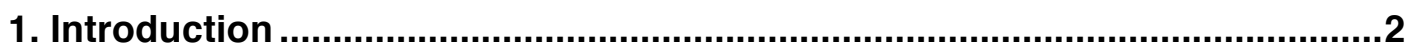

2. Literature review of HCPV LCAs ..............................................................

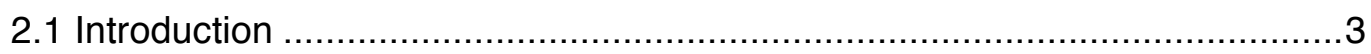

2.2 Assessment Criteria ............................................................................

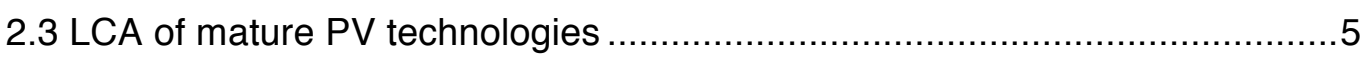

2.4 LCA of HCPV technologies ............................................................

3. Cumulative energy demand and embedded GHG emissions of the Fullsun

HCPV module ....................................................................................

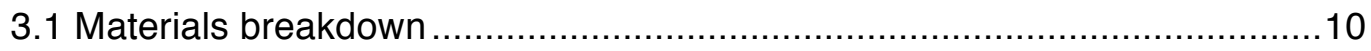

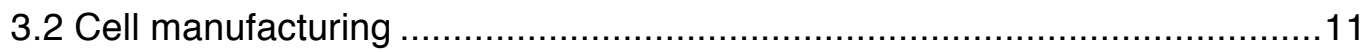

3.3 Module manufacturing........................................................................

3.4 Module CED and embedded GHGs ..................................................12

4. Assessment of system deployment ………………................................14

4.1 System description and deployment location .............................................14

4.2 System EPBTs, CPBTs and emissions intensities.....................................16

4.3 Emissions intensity comparison with other renewable technologies.............18

4.4 Levelised cost of electricity ………………………............................19

4.5 Competitiveness with grid electricity ……………………………….....20

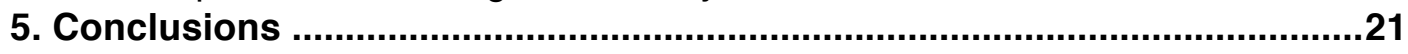

6. Acknowledgements ....................................................................................22

7. Bibliography .................................................................................................23 


\section{Introduction}

Photovoltaic (PV) technology has the potential to provide electricity at low cost and with significantly lower greenhouse gas (GHG) emissions than fossil fuel energy sources. At present mature PV technologies, such as silicon and thin film technologies, dominate the worldwide market in terms of deployment[1] with emerging low cost or very high efficiency technologies holding a very small market share.

High concentration photovoltaics (HCPV) aim to provide an alternative to traditional PV designs. Instead of using large areas of solar cell to convert sunlight into electricity, HCPV relies on concentrating optics systems to focus sunlight onto much smaller areas. This allows higher efficiency cells to be used and a potential reduction in cost by replacing expensive semiconductor based solar cells with cheaper lenses and mirrors. The optical systems employed by HCPV can utilise only the light that falls at normal incidence to the surface of the module (direct normal irradiance, DNI), which limits their deployment to desert regions.

The efficiency of the multijunction cells used in HCPV applications has consistently risen at a rate superior to first and second generation cells used in other technologies[2]. However their commercial deployment has been significantly smaller in comparison to mature technologies: a cumulative installed capacity in 2015 of $340 \mathrm{MW}$ for CPV[3] is dwarfed by over $100 \mathrm{GW}$ of crystalline silicon [4], and this has hampered its competitiveness on the grounds of cost. Although system prices are decreasing and are predicted to be as low as $\$ 1.10 / W_{p}$ by 2020[5], the HCPV industry will still need a competitive advantage to penetrate the market dominance of mature PV. At present one advantage is the superior performance of the III-V cells used for HCPV over other technologies as operating temperatures increase, making them more attractive to emerging markets in countries with high irradiance. Another advantage could come from the growing desire of companies and governments to reduce their environmental impact to mitigate anthropogenic climate change.

To track the movement of the sun across the sky many established HCPV systems rely on large arrays of modules mounted on a single heavy pedestal. This provides structural support against high winds but significantly impacts the amount of materials used in construction, both for the tracking system and the any heat sinks required to cool the modules for optimal operating conditions. Increased materials usage results in a higher cumulative energy demand (CED), a measure of the energy embedded in a module or system, and an increase in GHG emissions from its production. By using more lightweight designs, HCPV modules can benefit not only from lower materials 
usage, embedded energy and GHG emissions, but also the use of smaller tracking systems which will provide additional materials savings.

Savings in the energy embedded in manufacture will increase the rate at which a PV technology can reduce net GHG emissions when deployed. The effect of module design and manufacture process on the CED of a PV module has been studied in some detail for flat plate technologies [6-8] but only a few such assessments of CPV modules have been made[9-13], despite their potential value of such assessments in guiding the design of modules with maximum emissions mitigation potential.

In this study we present the results of a life cycle analysis (LCA) of a module design produced by Fullsun Photovoltaics Limited, chosen for its lightweight design and reduced materials consumption. A review of other HCPV LCAs is given in Section 2 for comparison. A description of the module and the materials and processes used in its construction are considered in Section 3 and the resulting embedded energy and GHGs are reported. These are compared to previous HCPV LCAs. Section 4 considers the deployment of a system using this module design and the resulting energy payback times (EPBTs) and $\mathrm{CO}_{2 e q}$ payback times (CPBT) in addition to a comparison of emissions intensities of other renewable energy technologies. Section 5 provides summary and conclusion of the study.

\section{Literature review of HCPV LCAs}

\subsection{Introduction}

In the case of PV, the most common forms of life cycle analysis (LCA) aim to quantify the energy used and the GHGs emitted in the construction of the module or system[14]. These can vary in scope and assessment criteria, as well as in the boundaries of the system considered. This is motivated by the GHG mitigation potential of PV technologies through their deployment and can be used by stakeholders to justify the use of PV technologies as a lowcarbon electricity option.

As PV technologies evolve, the processes and materials used in their production also change. This affects their environmental impact and as a result LCAs must be periodically performed to ensure the accuracy of their findings, in particular when being used to predict the effects of future deployments. As will be shown in the subsequent sections, the LCA of HCPV lags behind other PV technologies and no analysis has yet been performed for lightweight modules similar to the one described in this study.

\subsection{Assessment Criteria}

This study will only consider the two most directly relevant factors to climate change mitigation: the CED and embedded GHGs. Other assessment criteria include factors that describe the impact of PV deployment on the environment, 
for example materials depletion, the use of toxic chemicals, or the effect on human health[15]. The functional unit considered in the first part of this study will be one Fullsun module, but for comparability to other studies this will also be expressed in terms of the power (with a functional unit of $1 W_{p}$ ) of the module. When considering the system deployment, the functional unit will be one fully installed $6 \mathrm{~kW}_{\mathrm{p}}$ system, and also 1 kilowatt hour ( $\mathrm{kWh}$ ) of electricity at the point of use when comparing specific emissions.

The cumulative energy demand (CED) is the total energy required to produce the module[15]. This includes not only the energy used in manufacturing the module at the factory but also that which is embedded in the materials, for example from mining metal ore or tempering glass. The CED is expressed in terms of megajoules of equivalent primary energy $\left(\mathrm{MJ}_{\mathrm{EPE}}\right)$ which accounts for the efficiencies of energy conversion in processing.

Analogous to the CED is the embodied emissions, a measure of the cumulative GHG emissions released in the construction of the module. This is expressed in terms of their equivalent global warming potential over an integrated 100-year time horizon in kilograms of $\mathrm{CO}_{2}\left(\mathrm{kgCO}_{2 e q}\right)[16]$.

To consider the efficacy of installed HCPV systems, the energy payback time (EPBT) is considered. This is the measure of the operation time required for the system to generate the equivalent primary energy as was used in its construction and deployment and is a common metric in assessing and comparing HCPV systems. This assumes the HCPV system is replacing electricity generated by the local grid and is defined[15] as

$$
E P B T=\frac{E_{\text {mod }}+E_{t r a c k}+E_{B O S}+E_{t r a n s}+E_{i n s}+E_{E O L}}{\frac{E_{g e n}}{\eta_{E}}-E_{O M}}
$$

The terms in the numerator of equation 1 refer to the primary energy demand of the module, $\left(E_{\text {mod }}\right)$ tracker $\left(E_{\text {track }}\right)$, balance of systems $\left(E_{B O S}\right)$, transport $\left(E_{\text {trans }}\right)$, installation $\left(E_{\text {ins }}\right)$ and end-of-life management $\left(E_{E O L}\right)$. In the denominator, $E_{g e n}$ is the annual electricity generated by the system, $\eta_{E}$ is the grid efficiency (average primary energy to electricity conversion ratio at the demand side) and $E_{O M}$ is the annual primary energy demand of operation and maintenance.

The analogous metric for GHG emissions is the $\mathrm{CO}_{2 \text { eq }}$ payback time (CBPT). As the HCPV system generates electricity with negligible GHG emissions once it is operational, it supplies electricity to the local grid network that would otherwise have been produced from other sources with subsequent emissions. Once enough energy has been produced such that these avoided emissions equal the total embedded emissions in the system, the CPBT is reached. It can be expressed as

$$
C P B T=\frac{C_{m o d}+C_{t r a c k}+C_{B O S}+C_{t r a n s}+C_{i n s}+C_{E O L}}{\left(E_{g e n}-E_{O M}\right) \eta_{C}}
$$


where the terms in the numerator of the equation refer to the embodied GHGs of the module $\left(\mathrm{C}_{\text {mod }}\right)$, tracker $\left(\mathrm{C}_{\text {track }}\right)$, balance of systems $\left(\mathrm{C}_{\mathrm{BOS}}\right)$, transport $\left(\mathrm{C}_{\text {trans }}\right)$, installation $\left(\mathrm{C}_{\text {ins }}\right)$ and end-of-life management $\left(\mathrm{C}_{\mathrm{EOL}}\right)$ and $\eta_{C}$ is the emissions intensity of the local grid network (average GHG emissions of converting primary energy to electricity at the demand side). The EPBT and CPBT allow comparative assessments of different module designs, technologies, deployment locations and other parameters from an environmental perspective.

The final environmental criterion used in this study is the emissions intensity of the system. This is the measure of the GHG emissions expressed as an equivalent of $\mathrm{CO}_{2}$ per $\mathrm{kWh}$ of electricity used at the point of demand, averaged over the lifetime of the system. This is calculated as

$$
\text { Emissions intensity }=\frac{C_{m o d}+C_{t r a c k}+C_{B O S}+C_{t r a n s}+C_{i n s}+C_{E O L}}{\sum_{t}^{T}\left(E_{\text {gen }}^{t}-E_{O M}^{t}\right)}
$$

for a system lifetime of $T$ years and $E_{\text {gen }}^{t}$ is the energy generated by the system in year $t$. This calculation allows a comparison not only of different potential installation areas, but also a comparison with other technologies and their relative performance in mitigating GHG emissions from electricity production. Assessment criteria such as EPBT and emissions intensity are generally well correlated but their exact relationship not fixed, for example because of manufacturing processes using different ratios of electrical and thermal energy or being performed in locations with different carbon intensities of their grid networks.

Finally, the economic cost of the system will be assessed using the levelised cost of electricity (LCOE). The formula for LCOE is given[4] by

$$
L C O E=\frac{\sum_{t}^{T} \frac{I_{t}}{(1+d)^{t}}}{\sum_{t}^{T} \frac{E_{t}}{(1+d)^{t}}}
$$

for annual investment in the system $I_{t}$ and annual electricity production $E_{t}$ in the year $t$, with a system lifetime of $T$ years and a discount rate $d$. The LCOE provides a measure of the cost of electricity over the lifetime of the system and allows a comparison to other generation technologies.

\subsection{LCA of mature PV technologies}

LCA techniques have been applied most commonly to mature technologies, as would be expected by their greater deployment. Studies of the use of silicon and thin film technologies in applications such as domestic rooftop, grid-scale power plants, off-grid electricity systems or for standalone solarpowered devices[8, 14, 17-23] have been considered, and in a range of 
locations worldwide. The volume of the studies for mature technologies is too great to analyse sufficiently in this paper, but a synthesis of the results can be produced in a harmonisation process.

As the assumptions and specifications used for the each LCA studies vary, often significantly, harmonisation can be used to compare results in a uniform way. This is done by first gathering a group of studies for comparison and filtering out those that do not reach the required standard of detail or rigour. The remaining studies are then normalised by adjusting the parameters used to chosen values which are now common to the entire group, for example the performance ratio of the system or local irradiance levels, allowing for a direct and fair comparison and conclusions.

One such harmonised study was undertaken by Hsu et al. (2012)[6] on the life cycle GHG emissions of crystalline silicon (c-Si) PV. After an initial screening yielded 129 studies of $\mathrm{C}-\mathrm{Si}$ LCAs, they were then assessed for quality, transparency and usability, including the explicit statement of key parameters (namely module conversion efficiency, performance ratio, irradiance and system lifetime). Of the initial 129 studies, 13 met the criteria and featured 41 estimates of embedded emissions. After harmonising the results, the median estimate for specific emissions for all studies was found to be $45 \mathrm{gCO}_{2 e q} / \mathrm{kWh}$ under an irradiance of $1700 \mathrm{kWh} / \mathrm{m}^{2} / \mathrm{yr}$ for all studies. For ground-mounted installations the harmonised median was $48 \mathrm{gCO}_{2 \mathrm{eq}} / \mathrm{kWh}$, and for roofmounted systems it was $44 \mathrm{gCO}_{2 \mathrm{eq}} / \mathrm{kWh}$; when segregating by technology type, the emissions intensities were 40 and $47 \mathrm{gCO}_{2 \mathrm{eq}} / \mathrm{kWh}$ for monocrystalline silicon (mono-Si) and multicrystalline silicon (multi-Si) respectively. When considering deployment in areas with high irradiance, considered to be $2400 \mathrm{kWh} / \mathrm{m}^{2} / \mathrm{yr}$, the median emissions intensity was 32 $\mathrm{gCO}_{2 \mathrm{eq}} / \mathrm{kWh}$.

The authors identified that efficiency advantages in mono-c-Si are approximately balanced out by a more energy intensive manufacturing process relative to multi-c-Si, and also that as efficiencies increase and materials usage decrease for both technologies then lower emissions intensities can be achieved[6]. Another alternative to reduce emissions intensity can be to deploy thin film technologies, which have lower embedded energies and GHG emissions compared to $\mathrm{C}-\mathrm{Si}$ technologies[8]. A similar study, performed by Kim et al. (2012)[7] was undertaken for thin film technologies. A comparable harmonisation process was applied to amorphous silicon (a-Si), cadmium telluride (CdTe) and copper indium gallium diselenide (CIGS). Assuming deployment in high irradiance $\left(2400 \mathrm{kWh} / \mathrm{m}^{2} / \mathrm{yr}\right)$ areas, the emissions intensities were calculated to be 20,14 and 26 $\mathrm{gCO}_{2 e \mathrm{e}} / \mathrm{kWh}$ respectively for ground-mounted installations and 21,14 and 27 $\mathrm{gCO}_{2 \mathrm{e}} / \mathrm{kWh}$ for those mounted on roofs. Using this figure for irradiance leads to these values representing a reasonable estimate of the lower bounds of emissions intensities for mature PV technologies and as such the target for emerging technologies, such as HCPV, to reach in order to compete on the 
grounds of GHG emissions mitigation potential. A summary of these values is shown in Table 1.

\begin{tabular}{|c|c|c|c|c|}
\hline Technology & Installation type & $\begin{array}{l}\text { Irradiance } \\
\left(\mathrm{kWh} / \mathrm{m}^{2} / \mathrm{yr}\right)\end{array}$ & $\begin{array}{c}\text { Median emissions } \\
\text { intensity }\left(\mathrm{gCO}_{2 \mathrm{eq}} / \mathrm{kWh}\right)\end{array}$ & Study \\
\hline \multirow{3}{*}{$\mathrm{c}-\mathrm{Si}$} & Ground & 1700 & 48 & \multirow{5}{*}{$\begin{array}{c}\text { Hsu et } \\
\text { al.[6] }\end{array}$} \\
\hline & Roof & 1700 & 44 & \\
\hline & Both & 2400 & 32 & \\
\hline multi-Si & Both & 1700 & 40 & \\
\hline mono-Si & Both & 1700 & 47 & \\
\hline \multirow{2}{*}{$\mathrm{a}-\mathrm{Si}$} & Ground & 2400 & 20 & \multirow{6}{*}{$\begin{array}{c}\mathrm{Kim} e t \\
\text { al.[7] }\end{array}$} \\
\hline & Roof & 2400 & 21 & \\
\hline \multirow{2}{*}{ CdTe } & Ground & 2400 & 14 & \\
\hline & Roof & 2400 & 14 & \\
\hline \multirow{2}{*}{ CIGS } & Ground & 2400 & 26 & \\
\hline & Roof & 2400 & 27 & \\
\hline
\end{tabular}

Table 1 Summary of the median emissions intensities of harmonised LCA studies for mature PV technologies, both crystalline silicon (multi-Si and mono-Si) and thin films (a-Si, CdTe and CIGS).

\subsection{LCA of HCPV technologies}

LCAs of HCPV systems have also been conducted to assess their environmental impacts to judge both their own performance and in comparison to the benchmark set by mature technologies. One of the first was conducted by Peharz and Dimroth in 2005 as an analysis of the FLATCON® system designed by the Fraunhofer Institute for Solar Energy Systems[9]. The module operates at $500 x$ concentration and a module efficiency of $26 \%$ is assumed. This study considers the CED of a FLATCON® system manufactured in Germany and deployed in Spain and Germany, using EPBT as its primary evaluation criteria. CED contributions from the module manufacture, tracker, balance of systems and transportation are considered, but not any end of life aspects. The largest CED contributions were found to come from components made of zinced steel (such as the tracking system), the float glass used for the module body and transportation of the system from its production site to its final location. The resulting EPBTs are 8-10 months and 12-16 months for deployment in Spain and Germany respectively, which the authors favourably compare with of those of contemporary multi-Si PV systems (3-4 years) and solar thermal collectors (1-2 years). An extension of this study was performed by de Wild-Scholten et al. (2010)[10] which found a similar EPBT for deployment in Italy and calculated an emissions intensity of $18 \mathrm{gCO}_{2 \mathrm{eq}} / \mathrm{kWh}$.

An analysis of the SolFocus Gen1 HCPV system was undertaken by Der Minassians et al. (2006)[11]. The system's panel is made up of nine modules that are themselves made up of sixteen units, each unit being comprised of a PV cell and its associated concentrating optics. The optical system employed by this design consists of a concave primary mirror, a convex secondary mirror and a tertiary prism that supplies the cell with 500x concentrated light. As in the study by Peharz and Dimroth (2005), significant contributions to the CED came from the large amount of galvanised steel required by the tracking 
system. More significantly, however, was the embodied energy of the concentrator system: despite having relatively little energy embodied in the materials themselves, the transportation of the system from the supplier to the SolFocus plant comprised over $25 \%$ of the CED. The authors recommend reducing transportation distance to reduce the CED, and identified that using an alternative material for the tracker or reducing the volume of materials used would lower the EPBTs. Installations in two locations were considered and EPBTs of 1.5 years in California and 1.3 years in Arizona were reported.

For several years, Amonix (now Arzon Solar) was the leader in deployment in the HCPV industry with installations on the megawatt scale in both the USA and Europe[24]. LCAs of the Amonix system has been presented in the past $[14,25,26]$ with the most recent performed by Fthenakis and Kim (2013)[12]. The Amonix 7700 system consists of several large "MegaModules" operating at 500x concentration, mounted on a pedestal tracking system. The study considers all stages and components of the system lifetime, both in terms of CED and GHG emissions, and for installations in Las Vegas, NV, Phoenix, AZ and Glendale, AZ makes estimates of EPBTs (all 0.9 years) and emissions intensities (26, 27 and 27 $\mathrm{gCO}_{2 \mathrm{eq}} / \mathrm{kWh}$ respectively). As with Der Minassians et al. (2006)[11], significant contributions to the CED and GHG emissions are from the tracker, and also the heat sink required to cool the MegaModule to suitable operating temperatures.

APOLLON was a pan-European project that operated from 2008-2013 that investigated several aspects of the HCPV development including cell growth, field testing and environmental impact[13]. The modules supplied to the project were provided by SolTec International[10], operated at a module efficiency of $30 \%$ and used mirrors and optical elements fabricated from aluminium foil to focus light onto cells $30.7 \mathrm{~mm}^{2}$ in area[13]. Aluminium was found to be the greatest component by weight (being the main component in the frame, base, receiver support and heat sink) and as such had the greatest environmental impact, contributing $63 \%$ of the CED and $64 \%$ of the GHG emissions to the module construction. For deployment in Sicily, Italy (with a DNI of $1794 \mathrm{kWh} / \mathrm{m}^{2} / \mathrm{yr}$ ) an EPBT of 1.0 years and emissions intensity of 20 $\mathrm{gCO}_{2 \mathrm{eq}} / \mathrm{kWh}$ was calculated. Again, the authors compare this favourably with other PV and HCPV technologies and identify its competitiveness on grounds of sustainability.

A summary of HCPV LCAs was compiled by Kammen et al. (2011)[27]. Using data from the literature the LCAs of several studies, including those already mentioned in this review, were harmonised in a similar fashion to those of cSi[6] and thin film[7] PV to compare the state of technology. EPBTs of HCPV systems were found to be in the range of 0.5-1.2 years and emissions intensities were reported to be between 15-55 $\mathrm{gCO}_{2 \mathrm{eq}} / \mathrm{kWh}$ assuming a DNI of $2537 \mathrm{kWh} / \mathrm{m}^{2} / \mathrm{yr}$. The performance ratio used for harmonisation was set to be 0.75, which while typical and recommended for non-tracking PV LCAs[15] it is lower than used by some LCAs[12] and those found by field studies[28, 29]. 
This may result in higher than expected environmental impacts and an unfair comparison to other PV LCAs.

The modules and systems considered by the literature thus far, summarised in Table 2, have broadly similar designs. The use of heavy-duty pedestal trackers and the necessity for heat sinks for efficient operation contribute significantly to the CED and GHG emissions embedded in the system, but they nevertheless hold favourable EPBTs and emissions intensities in comparison to other, flat-plate PV technologies. In this study, a lightweight module design will be analysed to evaluate its effectiveness in reducing the overall environmental impact and as a result the GHG emissions mitigation potential will be assessed.

\begin{tabular}{|c|c|c|c|c|c|}
\hline System & $\begin{array}{c}\text { DNI } \\
\left(\mathrm{kWh} / \mathrm{m}^{2} / \mathrm{yr}\right)\end{array}$ & $\begin{array}{l}\text { EPBT } \\
\text { (Years) }\end{array}$ & $\begin{array}{c}\text { Emissions } \\
\text { intensity } \\
\left(\mathrm{gCO}_{2 \mathrm{eq}} / \mathrm{kWh}\right)\end{array}$ & $\begin{array}{l}\text { Module } \\
\text { CED } \\
\left(\mathrm{MJ} / \mathrm{W}_{\mathrm{p}}\right)\end{array}$ & Study \\
\hline \multirow{3}{*}{ FLATCON® } & 1900 & $0.7-0.8$ & NC & \multirow{3}{*}{5.8} & \multirow{2}{*}{$\begin{array}{l}\text { Peharz and Dimroth } \\
(2005)[9]\end{array}$} \\
\hline & 1000 & $1.0-1.3$ & $\mathrm{NC}$ & & \\
\hline & 1794 & 0.8 & 18 & & $\begin{array}{c}\text { de Wild-Scholten et } \\
\text { al. }(2010)[10]\end{array}$ \\
\hline \multirow{2}{*}{ SolFocus } & 1825 & 1.5 & $\mathrm{NC}$ & \multirow{2}{*}{12.9} & \multirow{2}{*}{$\begin{array}{l}\text { Der Minassians et } \\
\text { al. (2006)[11] }\end{array}$} \\
\hline & 2520 & 1.3 & $\mathrm{NC}$ & & \\
\hline \multirow{4}{*}{ Amonix 7700} & 1974 & 1.5 & 32 & \multirow{4}{*}{11.8} & $\begin{array}{c}\text { de Wild-Scholten et } \\
\text { al. (2010)[10] }\end{array}$ \\
\hline & 2600 & $\begin{array}{c}0.9 \\
(0.8)^{\star}\end{array}$ & $26(22)^{\star}$ & & \multirow{3}{*}{$\begin{array}{c}\text { Fthenakis and Kim } \\
(2013)[12]\end{array}$} \\
\hline & 2480 & $\begin{array}{c}0.9 \\
(0.8)^{*}\end{array}$ & $27(23)^{\star}$ & & \\
\hline & 2570 & $\begin{array}{c}0.9 \\
(0.8)^{*}\end{array}$ & $27(23)^{\star}$ & & \\
\hline APOLLON & 1794 & 1.0 & 20 & 8.3 & $\begin{array}{l}\text { Timò et al. } \\
(2014)[13]\end{array}$ \\
\hline
\end{tabular}

Table 2 Summary of reported results for other HCPV LCAs. A normalised module CED (in units of primary energy used in production per system Watt-peak installed capacity reported) is provided as a measure of comparison between systems of different sizes. NC (Not Considered) is used in place of values that are either not calculated or not present in the reports. *: Results shown are for then-current (2009) values, with then-future (2011) estimates given in brackets.

\section{Cumulative energy demand and embedded GHG emissions of the Fullsun HCPV module}

The Fullsun HCPV module[30] features 391 III-V multijunction PV cells mounted on a printed circuit board (PCB) under silicone secondary optical elements (SOEs), which are encased in an aluminium case under a Fresnel lens matrix made of silicone on low-iron float glass. The module backplane fulfils the need for cooling the cells, and as such no additional heat sink is required. The module measures $600 \mathrm{~mm}$ by $450 \mathrm{~mm}$ in area (total area $0.27 \mathrm{~m}^{2}$ ) and is $48 \mathrm{~mm}$ thick. It operates at $625 \mathrm{x}$ concentration with an acceptance angle of $\pm 0.8^{\circ}$. The module DC efficiency is taken to be $34 \%$ under standard test conditions, extrapolated from current performance values of $30 \%$ using $37 \%$ efficient cells under the assumption that optical and 
electrical losses remain the same when using $42 \%$ efficient cells, resulting in a rated capacity of $83 W_{p}$.

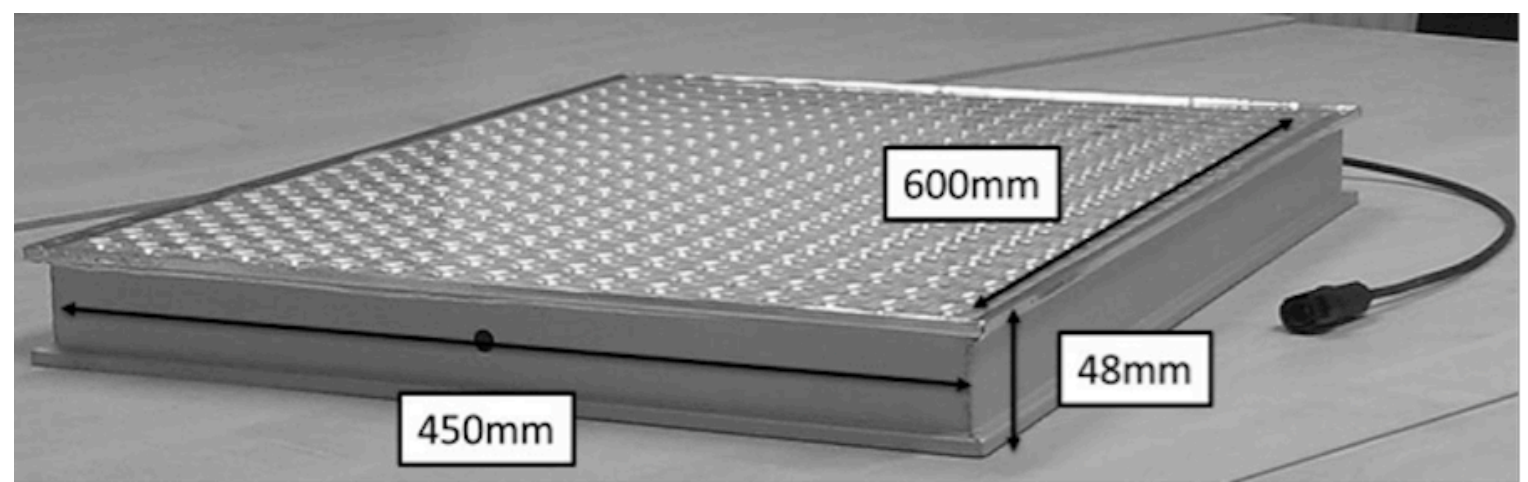

Figure 1 The Fullsun HCPV module with dimensions shown.

The module is designed to be thinner and more lightweight than those used by other HCPV systems, with dimensions similar to flat-plate PV modules. The modules are produced at a pilot-scale facility in Yorkshire, United Kingdom.

\subsection{Materials breakdown}

A breakdown of the components of the module is given in Table 3 and the materials composition by mass, totalling $4.2 \mathrm{~kg}$, is shown in Table 4 and Figure 2. Masses of materials used were calculated from technical drawings or from direct measurement from the assembly line.

\begin{tabular}{|c|c|c|c|}
\hline \multirow{2}{*}{ Component } & Material & Mass (kg) & $\begin{array}{c}\text { Mass } \\
\text { Fraction (\%) }\end{array}$ \\
\hline \multirow{2}{*}{ Lens } & Glass & 1.986 & 47.3 \\
\cline { 2 - 4 } & Silicone & 0.300 & 7.1 \\
\hline \multirow{2}{*}{ PCB backplane } & Aluminium & 1.072 & 25.5 \\
\cline { 2 - 4 } & Copper & 0.159 & 3.8 \\
\hline Walls & Aluminium & 0.452 & 10.8 \\
\hline Sealant & Silicone & 0.041 & 1.0 \\
\hline PV cells & Semiconductor & 0.042 & 1.0 \\
\hline Bypass diodes & Semiconductor & 0.004 & 0.1 \\
\hline SOEs & Silicone & 0.000 & 0.0 \\
\hline Power connectors & Cable & 0.088 & 2.1 \\
\hline Total & & 4.200 & 100.0 \\
\hline
\end{tabular}

Table 3 Breakdown of the Fullsun HCPV module in terms of its constituent components and their fractional contribution to the total mass.

\begin{tabular}{|c|c|c|}
\hline Material & Mass (kg) & $\begin{array}{c}\text { Mass } \\
\text { Fraction (\%) }\end{array}$ \\
\hline Glass & 1.986 & 47.3 \\
\hline Aluminium & 1.525 & 36.3 \\
\hline Silicone & 0.341 & 8.1 \\
\hline Copper & 0.214 & 5.1 \\
\hline Cables & 0.088 & 2.1 \\
\hline Semiconductors & 0.046 & 1.1 \\
\hline Total & $\mathbf{4 . 2 0 0}$ & $\mathbf{1 0 0 . 0}$ \\
\hline
\end{tabular}

Table 4 Materials used in the construction of the Fullsun HCPV module and their fractional contribution to the total mass. 


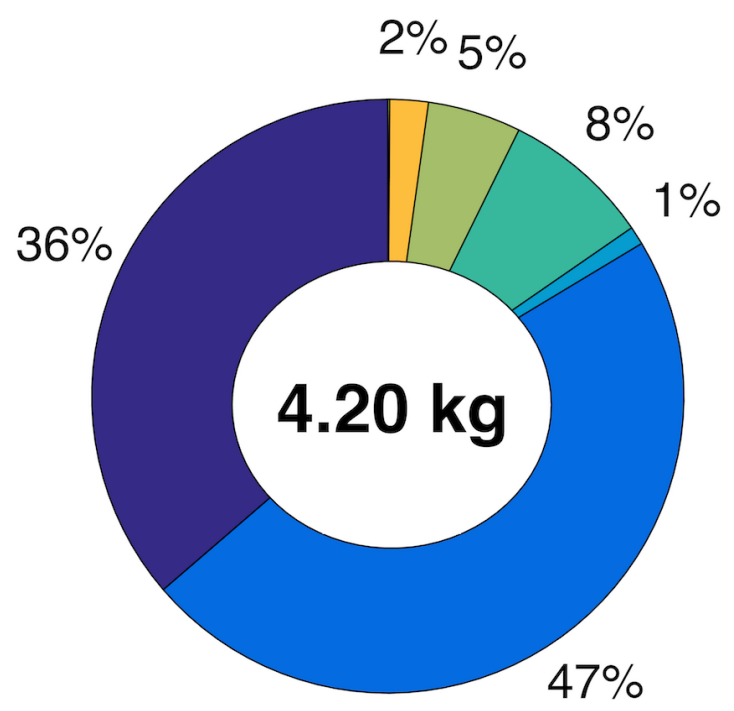

\section{$\square$ Aluminium $\square$ Glass $\square$ PV cells $\square$ Silicone $\square$ Copper $\square$ Cables $\square$ Electronics Figure 2 Materials breakdown of one Fullsun HCPV module, with a mass of $4.20 \mathrm{~kg}$.}

Similarly to other studies, the greatest contributors to the mass of the Fullsun module are the structural components such as the backplane, walls and lens array. Low-iron float glass, which makes up the matrix of Fresnel lenses, is the most massive single material, followed by aluminium from the frame of the module. Although numerous, the PV cells and bypass diodes that make up the electronic circuitry of the module contribute very little to the overall weight. At just $4.2 \mathrm{~kg}$ the module is light enough to be mounted on trackers that do not require heavy foundations, with a mounting capacity of $50.6 \mathrm{~kg} / \mathrm{kW}$.

\subsection{Cell manufacturing}

The manufacturing processes of the III-V multijunction solar cells similar to those used in the Fullsun module have not been the subject of many LCAs, however, the environmental impact of the cells is taken from Kim et al. (2008)[26] which analyses the impact of manufacturing GalnP/GalnAs/Ge cells through a metal-organic vapour-phase epitaxy process by Spectrolab. This was used by Fthenakis and Kim (2013)[12] who assumed a 10\% loss of inputs (which is also assumed in this work) and a cell efficiency of $37 \%$. To reflect improvements in commercial cell efficiencies[1] the cells in the Fullsun module are assumed to operate at $42 \%$ under standard test conditions[1, 31].

\subsection{Module manufacturing}

The major manufacturing processes used in the production of the module are assessed. The include using pick and place machines to put the singulated die onto a lead frame, wire bonding of PV cells to the lead frame, moulding and curing the silicone SOEs to form receiver packages, screen printing solder onto the $\mathrm{PCB}$, placing the receiver packages onto the $\mathrm{PCB}$, curing the solder and assembling the module. Some of these processes, for example joining the frame walls, are currently performed manually and as such their environmental impact is not considered. 


\subsection{Module CED and embedded GHGs}

The majority of the CED and embedded GHGs come from the materials used in the construction of the module detailed in Section 3.1, with their contributions to the total being the product of the mass of material used and its energy or GHG intensity. Where appropriate the intensity values are taken from the Inventory of Carbon and Energy (2011)[32] which best represents the impact of the current manufacturing location, or otherwise values were taken from comparable previous HCPV LCA studies[9, 12]. Contributions from sealants were taken from a relevant environmental assessment journal article[33] and the impact of power connectors was calculated from industrial literature[34]. Bypass diodes were assumed to have the same embedded energy and GHGs as PV cells per unit volume; owing to their relative simplicity this is likely to be a conservative estimate.

Energy and GHGs from processes [35-40] are calculated from datasheets describing the energy requirements of each of the machines used in the manufacturing process detailed in Section 3.3. For grid electricity, a conversion ratio of primary energy to electricity of 0.29 and the local carbon intensity of the United Kingdom is assumed[40]. Transport of module components from suppliers to the Fullsun factory [41-44] are considered, but not those from transporting the module to installation sites and from the endof-life contributions; these are assessed in Section 4.

Materials losses during the manufacturing process are included at $10 \%$ for PV cells[12], wastage of silicone sealant and glass breakages, and $5 \%$ for materials loss for metal components. The results for the Fullsun module are shown in Table 5 and Figure 3.

\begin{tabular}{|c|c|c|c|c|c|c|}
\hline $\begin{array}{c}\text { Module } \\
\text { component }\end{array}$ & $\begin{array}{c}\text { Energy } \\
\text { Intensity } \\
\left(\mathrm{MJ}_{\mathrm{EPE}} / \mathrm{kg}\right)\end{array}$ & $\begin{array}{c}\text { Embedded } \\
\text { Energy } \\
\text { (MJ) }\end{array}$ & $\begin{array}{c}\text { Energy } \\
\text { Fraction } \\
(\%)\end{array}$ & $\begin{array}{c}\text { GHG } \\
\text { Intensity } \\
\left(\mathbf{k g C O}_{2 \mathrm{eq}} / \mathrm{kg}\right)\end{array}$ & $\begin{array}{c}\text { Embedded } \\
\text { GHG } \\
\left(\mathrm{kgCO}_{2 \mathrm{eq}}\right)\end{array}$ & $\begin{array}{c}\text { GHG } \\
\text { Fraction } \\
(\%)\end{array}$ \\
\hline Lens & $13.2[9]$ & 31.9 & 9.0 & $0.9[32]$ & 2.8 & 10.2 \\
\hline \multirow{2}{*}{ Backplane } & $143.0[12]$ & \multirow{2}{*}{172.9} & \multirow{2}{*}{48.6} & $10.2[12]$ & \multirow{2}{*}{11.9} & \multirow{2}{*}{42.7} \\
\hline & 69.0 [32] & & & 2.7 [32] & & \\
\hline Lead frame & 69.2 [32] & 4.0 & 1.1 & 2.7 [32] & 0.2 & 0.6 \\
\hline Walls & $143.0[12]$ & 67.9 & 19.1 & $10.2[12]$ & 4.8 & 17.4 \\
\hline Sealant & $10.0[33]$ & 0.5 & 0.1 & 2.9 [32] & 0.1 & 0.5 \\
\hline PV cells & - & $4.2[26]$ & 1.2 & - & $0.2[26]$ & 0.6 \\
\hline Bypass diodes & - & 0.4 [26] & 0.1 & - & $0.02[26]$ & 0.1 \\
\hline $\begin{array}{c}\text { Power } \\
\text { connectors }\end{array}$ & $\begin{array}{c}150.0[12, \\
34]\end{array}$ & 13.2 & 3.7 & $7.6[12,34]$ & 0.7 & 2.4 \\
\hline Shipment & - & 5.6 & 1.6 & - & 0.4 & 1.3 \\
\hline Process & - & 55.1 & 15.5 & - & 6.8 & 24.2 \\
\hline Total & & 355.3 & 100.0 & & 27.9 & 100.0 \\
\hline
\end{tabular}

Table 5 The primary energy and GHG emissions embedded in one Fullsun module, broken down by components. 

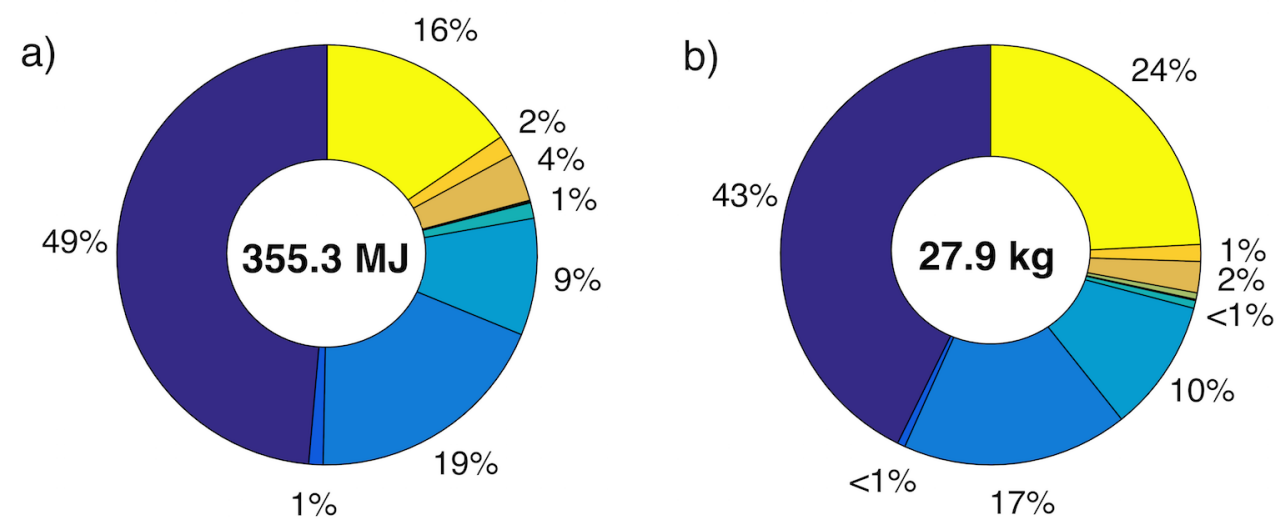

$\square$ Backplane $\square$ Leadframe $\square$ Walls $\square$ Lens $\square$ Cells

$\square$ Electronics $\square$ Sealant $\square$ Cables $\square$ Parts shipment $\square$ Process

Figure 3 Cumulative energy demand (left) and embedded greenhouse gas emissions (right) of one Fullsun HCPV module.

The total module CED to the factory gate is $355.3 \mathrm{MJ}_{E P E}$ and the embedded emissions are calculated to be $27.9 \mathrm{kgCO}_{2 \mathrm{eq}}$. Despite being the heaviest single component, the lens contributes a relatively small fraction of the overall environmental impact. More significant is the impact from the other structural components such as the backplane and sidewalls; the energy-intensive process of mining and smelting aluminium contributes significantly. This highlights the advantage of having a low profile, lightweight module as the reduced materials usage has helped to lower the overall impact.

The electronic components, such as the PV cells and bypass diodes, contribute very little to the overall impact. Shipment of parts also adds only a small amount to the total CED and embedded GHGs, suggesting that the factory location is not a significant factor for the Fullsun module. In contrast to the SolFocus supply chain, where the concentrating optics were shipped from New York to California for assembly[11], components for the Fullsun system are sourced from the UK or shipped by sea from European suppliers. Process energies contribute $15.5 \%$ of the CED and $24.2 \%$ of the embodied GHGs, which could be reduced by moving production processes throughout the value chain to less carbon-intensive grid; Spain, for example, has a low grid carbon intensity of $291 \mathrm{gCO}_{2 \mathrm{eq}} / \mathrm{kWh}$ in comparison to $441 \mathrm{gCO}_{2 \mathrm{eq}} / \mathrm{kWh}$ for the UK where the modules are presently assembled[40]. In addition it would provide a suitable local market for the technology, reducing transport costs.

The module CED normalised by its power rating gives a value of $4.3 \mathrm{MJ} / \mathrm{W}_{\mathrm{p}}$. Compared with the values given in Table 2 the module compares favourably, as shown in Figure 4. As no heat sink is required then energy savings are made when compared to the Amonix 7700 system[12] and reduced impacts from transporting components give this design the advantage over the SolFocus module[11]. The design of the module invests proportionately more materials in the frame to minimise cooling requirements, which results in a 
normalised CED comparable to other systems, however the remaining materials savings results in the module reporting a lower environmental impact than the others in the literature. The contribution of the cells varies between systems as a result of two estimations their of embedded energy and GHGs: Der Minassians et al. (2006)[11] uses data from the analysis of the FLATCON system[9] and the later studies (including this analysis) use data from Kim et al. (2008)[26]. Successive decreases in cell contribution to the normalised CED are an artefact of increasing values of cell efficiency resulting in higher power ratings. As a comparison, if the Fullsun module were to have the normalised contribution from cells as the FLATCON system (1.66 MJ/W $\mathrm{W}_{\mathrm{p}}$ ), its total normalised CED would remain the lowest of all the considered systems $\left(5.89 \mathrm{MJ} / \mathrm{W}_{\mathrm{p}}\right)$.

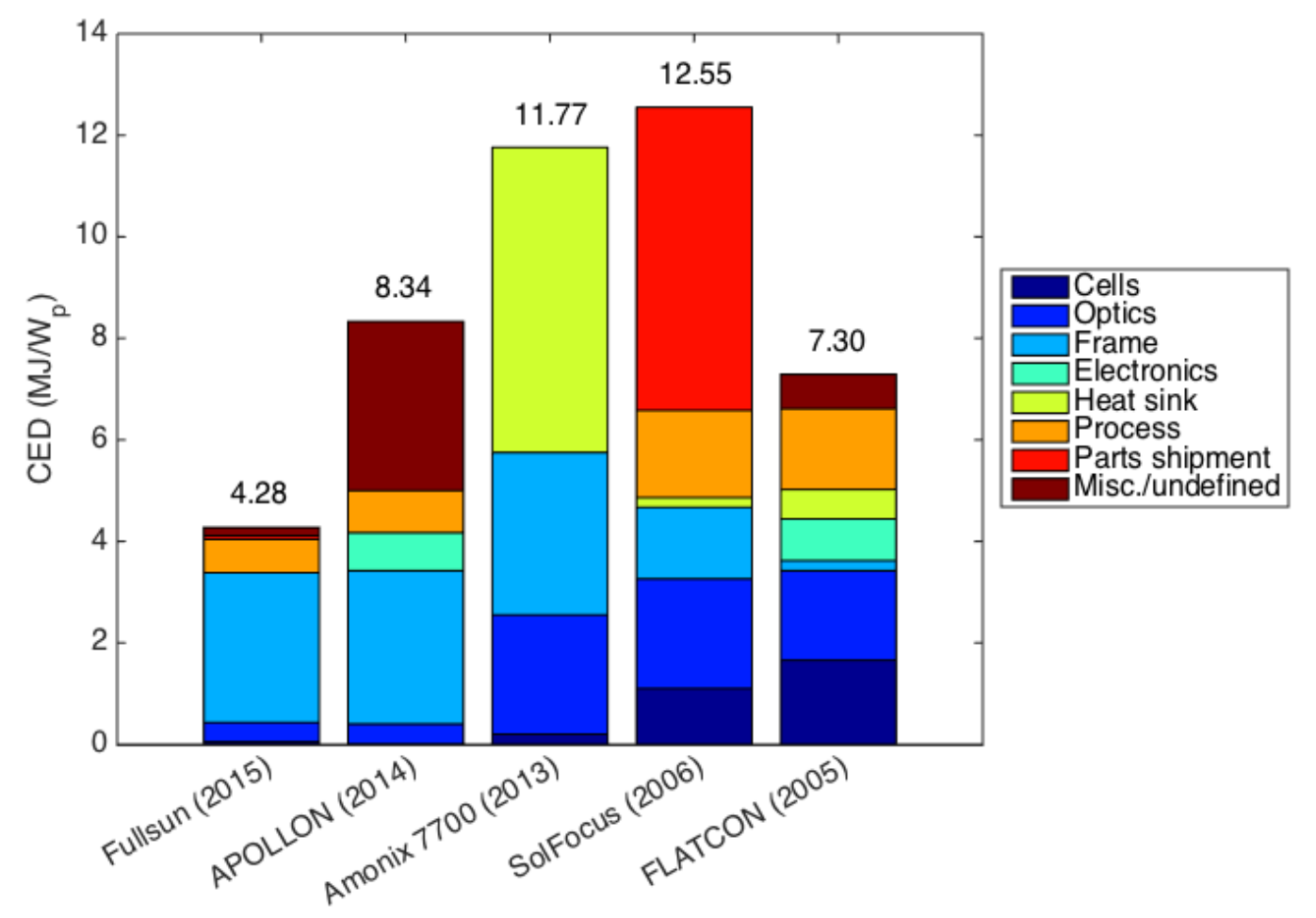

Figure 4 Comparison of CED values normalised per $W_{p}$ of the module for various HCPV systems analysed in the literature.

\section{Assessment of system deployment}

\subsection{System description and deployment location}

In order to judge the effectiveness of the technology in generating electricity and mitigating GHG emissions the deployment of HCPV systems, and not just modules, must be considered. Additional contributions towards the CED and embedded GHGs are introduced from the tracking system, shipment from factories to installation locations, assembly, balance of systems, operation and maintenance, and end-of-life disposal of the system.

The location of installed systems has a major effect on their performance as HCPV is highly dependent on the local DNI. The location determines the 
mitigation potential of the system, as generated electricity will be mitigating GHGs that would otherwise have been produced by the local grid. Losses of electricity between the point of generation and point of use also vary by location, which also influences contributions from transportation. HCPV is most effectively deployed in high DNI locations and as a result six suitable locations are considered in this study with information given in Table 6.

\begin{tabular}{|c|c|c|c|c|}
\hline Location & Country & $\begin{array}{c}\mathrm{DNI} \\
\left(\mathrm{kWh} / \mathrm{m}^{2} / \mathrm{yr}\right)[45]\end{array}$ & $\begin{array}{c}\text { Grid emissions } \\
\text { intensity } \\
\left(\mathrm{gCO}_{2 \mathrm{eq}} / \mathrm{kWh}\right)[40]\end{array}$ & $\begin{array}{c}\text { Grid } \\
\text { transmission } \\
\text { losses (\%)[46] }\end{array}$ \\
\hline Phoenix & USA & 2482 & 503 & 6 \\
\hline Seville & Spain & 2278 & 291 & 9 \\
\hline Tabuk & $\begin{array}{c}\text { Saudi } \\
\text { Arabia }\end{array}$ & 2668 & 754 & 9 \\
\hline Haixi & China & 2409 & 764 & 6 \\
\hline Alice Springs & Australia & 2668 & 823 & 5 \\
\hline Calama & Chile & 3322 & 441 & 7 \\
\hline
\end{tabular}

Table 6 Information about the six deployment locations considered by this study.

The system considered in this section is comprised of 72 Fullsun modules mounted on a commercially available foundationless tracker[47]. The total output of the system is $6 \mathrm{~kW}_{\mathrm{p}}$ and is assumed to operate at a performance ratio of 0.93 in line with previous studies $[9,12,48]$ and operational data from deployed systems[28, 29]. The modules are considered to degrade at $0.7 \%$ per annum over a lifetime of 30 years[15].

As no LCAs have been performed for lightweight tracker designs, its environmental impact of it has been estimated from extrapolations of the design and materials used in Fthenakis and Kim (2013)[12]. This is a conservative upper estimate as the tracker used in this study features a simpler design and less material is used. Additional estimates of the environmental impact of balance of systems, assembly and operations and maintenance were also taken from the same study based on data recorded from deployed systems.

The modules are shipped from the factory in Yorkshire, UK to installation locations via container ship and heavy truck, as are the trackers that are assumed to originate from the tracker company's headquarters. Distances were calculated using a shipping company web application[41] and environmental impacts were considered using energy and GHG emissions (per tonne-kilometre of shipment) of local transport[40, 43, 44].

The end of life management of the system is also treated in the same way as in Fthenakis and Kim (2013): the components are transported to a disposal facility $100 \mathrm{~km}$ from the installation site. Here the module components are separated at an energy demand of $0.24 \mathrm{MJ} / \mathrm{kg}[49]$ (the tracker materials are assumed to be homogenous enough not to require this[12]) and the system is shredded at an energy demand of $0.1 \mathrm{MJ} / \mathrm{kg}[49]$, both using local grid electricity. No energy benefit is considered from recycling and the shredding 
of components is the final stage of the system lifetime considered in this study.

\subsection{System EPBTs, CPBTs and emissions intensities}

The EBPTs, CBPTs and emissions intensities were calculated for each of the six locations and the results are shown in Table 7 and Figure 5.

\begin{tabular}{|c|c|c|c|c|}
\hline Location & $\begin{array}{c}\text { EPBT } \\
\text { (years) }\end{array}$ & $\begin{array}{c}\text { CPBT } \\
\text { (years) }\end{array}$ & $\begin{array}{c}\text { Emissions intensity } \\
\left(\mathrm{gCO}_{2 \text { eq }} / \mathrm{kWh}\right)\end{array}$ & $\begin{array}{c}\text { Local grid emissions intensity } \\
\left(\mathrm{gCO}_{2 \text { eq }} / \mathrm{kWh}\right)[40]\end{array}$ \\
\hline Phoenix, US & 0.30 & 0.48 & 9.0 & 503 \\
\hline Seville, ES & 0.32 & 0.88 & 9.4 & 291 \\
\hline Tabuk, SA & 0.28 & 0.30 & 8.3 & 754 \\
\hline Haixi, CN & 0.33 & 0.35 & 9.8 & 764 \\
\hline Alice Springs, AU & 0.29 & 0.29 & 8.8 & 823 \\
\hline Calama, CL & 0.22 & 0.40 & 6.5 & 441 \\
\hline
\end{tabular}

Table 7 EPBTs, CPBTs and emissions intensities of selected high-DNI deployment locations. The local grid emissions intensity is provided as a comparison to highlight the difference between these systems and the incumbent energy mix. 

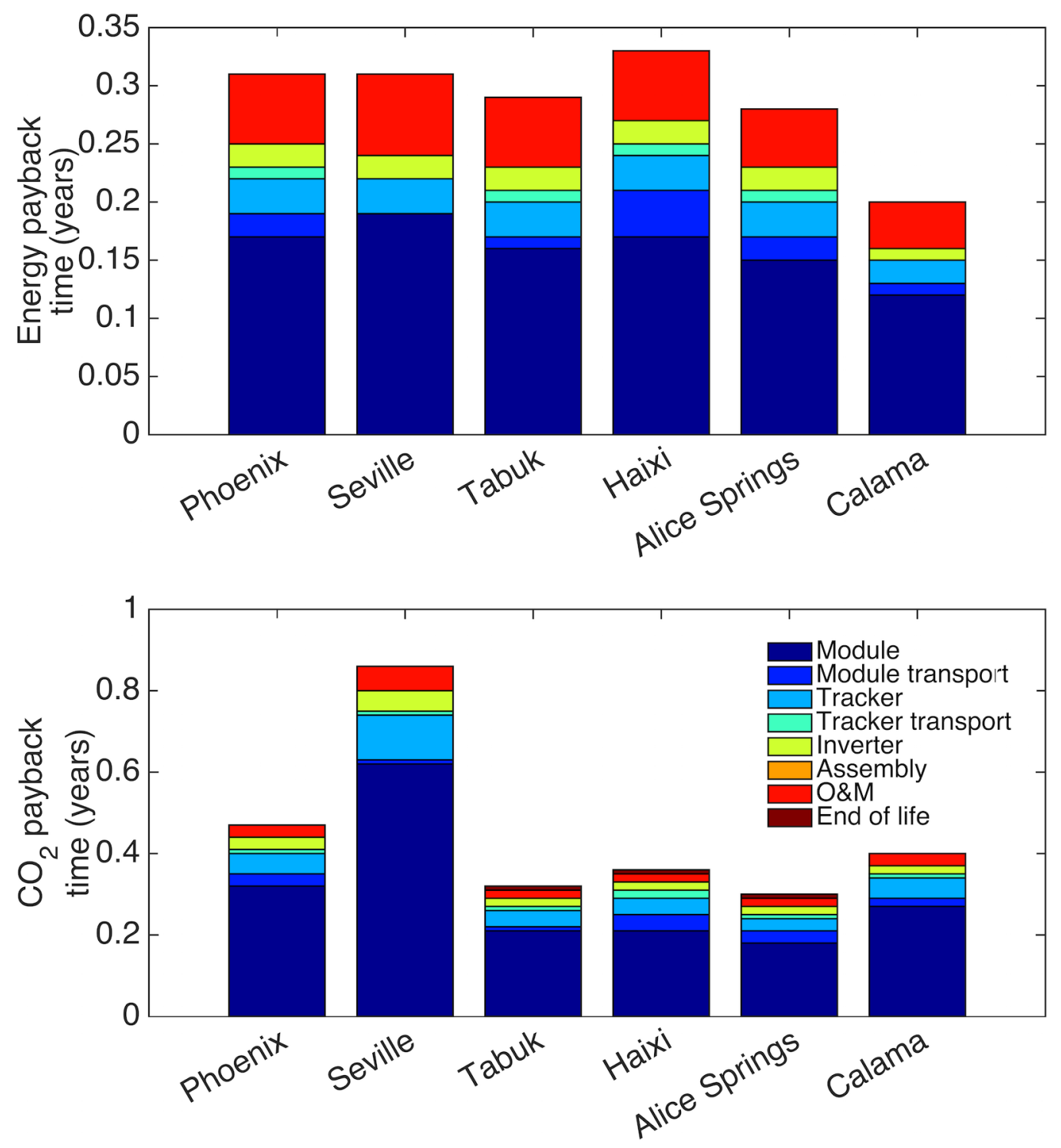

Figure 5 Energy (top) and GHG (bottom) payback times of a 6 kW system in selected deployment locations. Note the difference in vertical axis scales.

The EPBT is most dependent on the local levels of DNI and, as the locations were chosen to be the most favourable for HCPV deployment, they are all relatively similar in the range 0.29-0.33. One outlier is Calama in the Atacama Desert in Chile, which is one of the highest DNI areas in the world and as a result has an EPBT of just 0.22 years, or 80 days. Seville has the lowest DNI of the regions considered but not the highest EPBT; which is found at Haixi with 0.33 years (120 days) and arising from the increased contribution from transportation.

The CPBT is far more dependent on the local displaced carbon intensity. The results vary significantly, from $0.29-0.88$ years (106-321 days), as this measures the impact of the system in offsetting GHG emissions from the local grid network. For countries that already have high levels of low carbon electricity generation, such as Spain and Chile, the CPBT is higher than 
countries such as Australia and China where the electricity supply is more carbon intensive[40].

Uncertainty in the impact of the lightweight tracker could result in an underestimate of the EPBT and CBPT. Given that both the tracker and its transportation combined contribute between $12-14 \%$ of the CED and $13-15 \%$ of the embedded GHGs across all locations it is unlikely that it would affect the overall long-term environmental impact of the system. Even if the embedded energy and GHGs were double the estimated value, the payback times would increase by only around two weeks, far less than the lifetime of the system. Likewise distance to the disposal facility could vary significantly from the assumed $100 \mathrm{~km}$. Although transportation accounts for $25-30 \%$ the CED and $25-48 \%$ of the GHGs of the disposal process, the entire end of life contribution is only between $1-2 \%$ of the total. Even a significantly increased distance from the point of installation to the point of disposal would add just days to the overall payback period.

Whereas the EPBT and CPBT assess the initial impact of the system repaying its impact to the environment, the emissions intensity is a lifetimeaveraged metric that allows straightforward comparison to other electricity generation options. All of the locations considered in this study have CPV emission intensities of less than $10 \mathrm{gCO}_{2 \mathrm{eq}} / \mathrm{kWh}$, far lower than any conventional local generators. At the highest levels of insolation, Calama offers the lowest emissions intensity at just $6.5 \mathrm{gCO}_{2 \mathrm{eq}} / \mathrm{kWh}$. In contrast Haixi, which has comparatively moderate DNI levels and is the furthest location for transport, has an emissions intensity of $9.8 \mathrm{gCO}_{2 e q} / \mathrm{kWh}$ but remains far lower than the local grid at $764 \mathrm{gCO}_{2 \mathrm{eq}} / \mathrm{kWh}[40]$.

\subsection{Emissions intensity comparison with other renewable technologies}

In order for HCPV to be justified as a low-carbon power source its emissions intensity must compare favourably with alternative renewable energy sources. In addition to harmonised LCA studies on PV technologies performed by Hsu et al. (2012)[6] and Kim et al. (2012)[7], the Intergovernmental Panel on Climate Change (IPCC) compiled several comparable studies for other technologies[50]. The after normalisation the results were compiled and a range of values for specific emissions were reported, with the upper and lower bounds referring to the $25^{\text {th }}$ and $75^{\text {th }}$ percentile of values for that technology respectively.

The IPCC did not consider HCPV in their report, so to provide a suitable comparison the reported specific emissions of previous HCPV studies have been renormalized using the performance ratio used in this study (0.93) and using the irradiance levels typical of the southwest United States $(\mathrm{GHI}=2400$ $\mathrm{kWh} / \mathrm{m}^{2} /$ year, $\mathrm{DNI}=2482 \mathrm{kWh} / \mathrm{m}^{2} /$ year), which is the location chosen in the harmonised LCA studies for established technologies[6, 7]. This allows direct comparison between deployment options for the same scenario. To treat the data in the same way as the IPCC report and to minimise the effect of having 
a small number of studies to work from, the values for Fullsun HCPV and other HCPV were assumed to follow their own normal distributions and values for the $25^{\text {th }}$ and $75^{\text {th }}$ percentiles were extrapolated. For Fullsun HCPV this leads to a very small interquartile range (a result of the fact that the values come from several cases in the same study, rather than several different studies) but nonetheless gives an adequate first order estimation of how new compact, lightweight modules can compare.

The results of this comparison are shown in Figure 6. As expected the lower materials usage over previous HCPV technologies leads to a favourable outcome for the Fullsun modules, with specific emissions of around half their heavier counterparts. Importantly, at around $9 \mathrm{gCO}_{2 \mathrm{eq}} / \mathrm{kWh}$, the Fullsun HCPV modules also outperform thin film and silicon-based PV (as well as various types of concentrating solar power) when considered for deployment in the same location. These lightweight modules also have lower emissions intensities than onshore and offshore wind, nuclear, geothermal and biofuel energy. They are outperformed by hydropower and ocean power, however, the scale and location of these technologies mean they are very unlikely to directly compete for operational area and can be considered to be complementary.

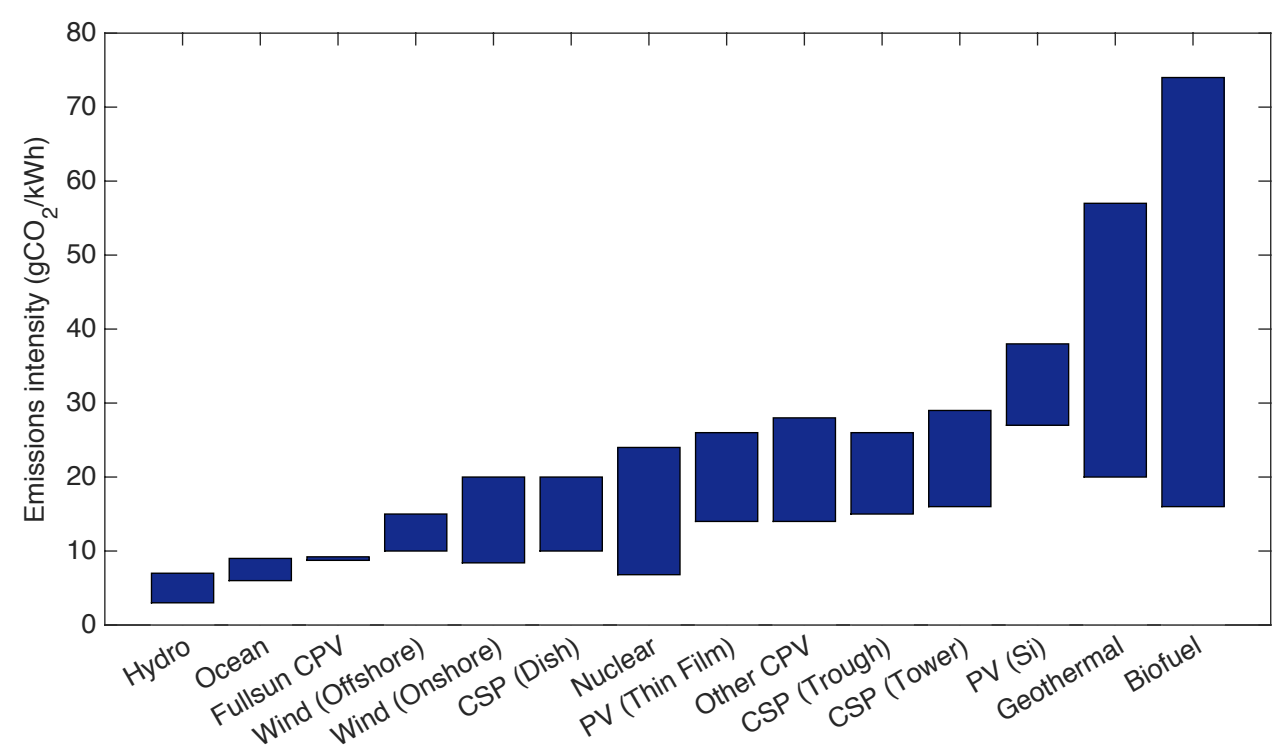

Figure 6 Emissions intensity of various low carbon technologies[6, 7, 50], including Fullsun HCPV.

\subsection{Levelised cost of electricity}

Whilst the Fullsun HCPV modules compare favourably with other technologies in terms of emissions intensity, in order to be deployed they must also compete on grounds of cost. Estimates of LCOE for HCPV systems range from $\$ 0.09-0.16 / \mathrm{kWh}$ depending upon deployment location, above that of other PV technologies $(\$ 0.07-0.11 / \mathrm{kWh})[3]$. When considering current costs from suppliers and savings gained from technical learning and high-volume production, Fullsun estimates a price of deployment in line with the $\$ 1.10 / \mathrm{W}_{\mathrm{p}}$ estimate given by Haysom et al. (2014)[5] for the system described 
previously. The LCOEs for the considered locations are shown in Figure 7 and the LCOE of flat-plate, optimally orientated silicon PV (at an installed cost of $\$ 1.00 / \mathrm{W}_{\mathrm{p}}$, the 2020 goal of the US Department of Energy's Sunshot initiative[51]) is shown as a comparison.

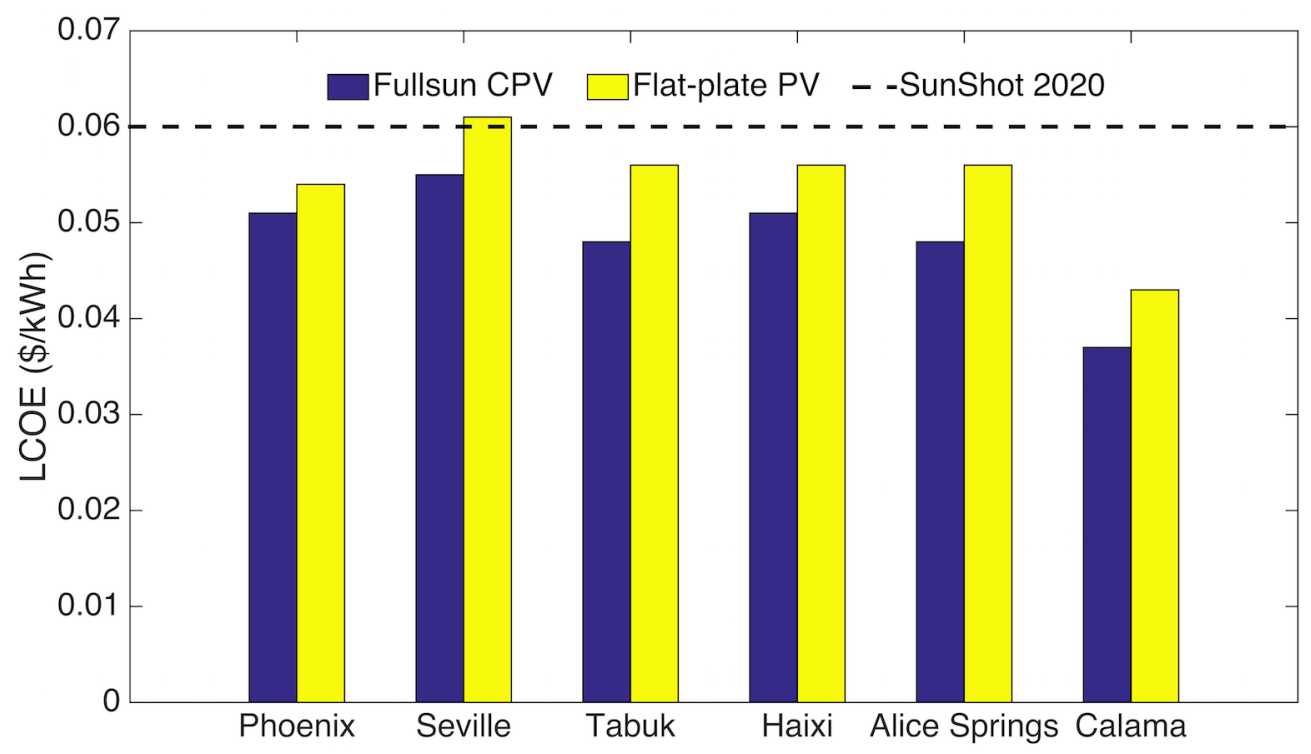

Figure 7 LCOEs of a Fullsun HCPV system and a flat-plate silicon system at projected 2020 prices.

The LCOE for the Fullsun systems depend most strongly on local irradiance and are approximately $5-15 \%$ lower than flat-plate silicon PV at around $\$ 0.05 / \mathrm{kWh}$. The lowest LCOE is found in Calama at $\$ 0.037 / \mathrm{kWh}$, whilst the highest is in Seville at $\$ 0.055 / \mathrm{kWh}$. Whilst the price of flat-plate PV is expected to drop further and may be more cost effective than HCPV at these prices, if HCPV can meet the costs estimates given by Haysom et al. then lightweight modules could meet the $\$ 0.06 / \mathrm{kWh}$ target set by the SunShot initiative[51]. The environmental benefits could make the difference in policymakers selecting lightweight HCPV modules for delivering cheap renewable energy.

\subsection{Competitiveness with grid electricity}

For any electricity source to be economically competitive its LCOE must be competitive with electricity supplied by the local grid or risk pricing itself out of contention for large-scale deployment. One proposed solution to mitigate climate by making low-carbon electricity sources more attractive is the introduction of a carbon price, with this additional cost increasing the price of an energy source in proportion to its emissions intensity. For lightweight HCPV modules, which produce power with emissions intensities far lower than that of the local grid network, a carbon price could significantly lower the barriers to deployment. 
Figure 8 shows the required carbon price to negate the difference between a low cost, high carbon intensity source of electricity and a competing technology of higher cost but with lower emissions. Dashed black lines correspond to the difference between Fullsun HCPV systems deployed in each location and the emissions intensity of the local grid[40] and solid white lines denote the expected carbon prices for 2020, 2025 and $2030(\$ 60, \$ 106$ and $\$ 180$ per tonne of $\mathrm{CO}_{2 e q}$ respectively)[52]. For 2020, it is projected that HCPV commands an LCOE premium on carbon emissions of almost $\$ 0.05 / \mathrm{kWh}$ in Australia, while in Spain where the carbon intensity of grid electricity is lower the premium drops to $\$ 0.015 / \mathrm{kWh}$. For deployment in the USA, the premium in LCOE sits at $\$ 0.03 / \mathrm{kWh}$ in 2020 to $\$ 0.05 / \mathrm{kWh}$ in 2025 , before reaching an expected $\$ 0.09 / \mathrm{kWh}$ in 2030 . This cost benefit arising as a result of reduced environmental impact of electricity generated by low carbon sources could provide the key in reducing the LCOE of HCPV to economically competitive levels. Furthermore, it has been shown that a rapid deployment of lower-carbon PV technologies can significantly increase potential reductions of GHG emissions during the first decades of technology growth, compared to current mature technologies[53]. Greater deployment, economies of scale and efficiencies in the manufacturing process could drive down prices to further lower LCOE and widen the range of potential installation.

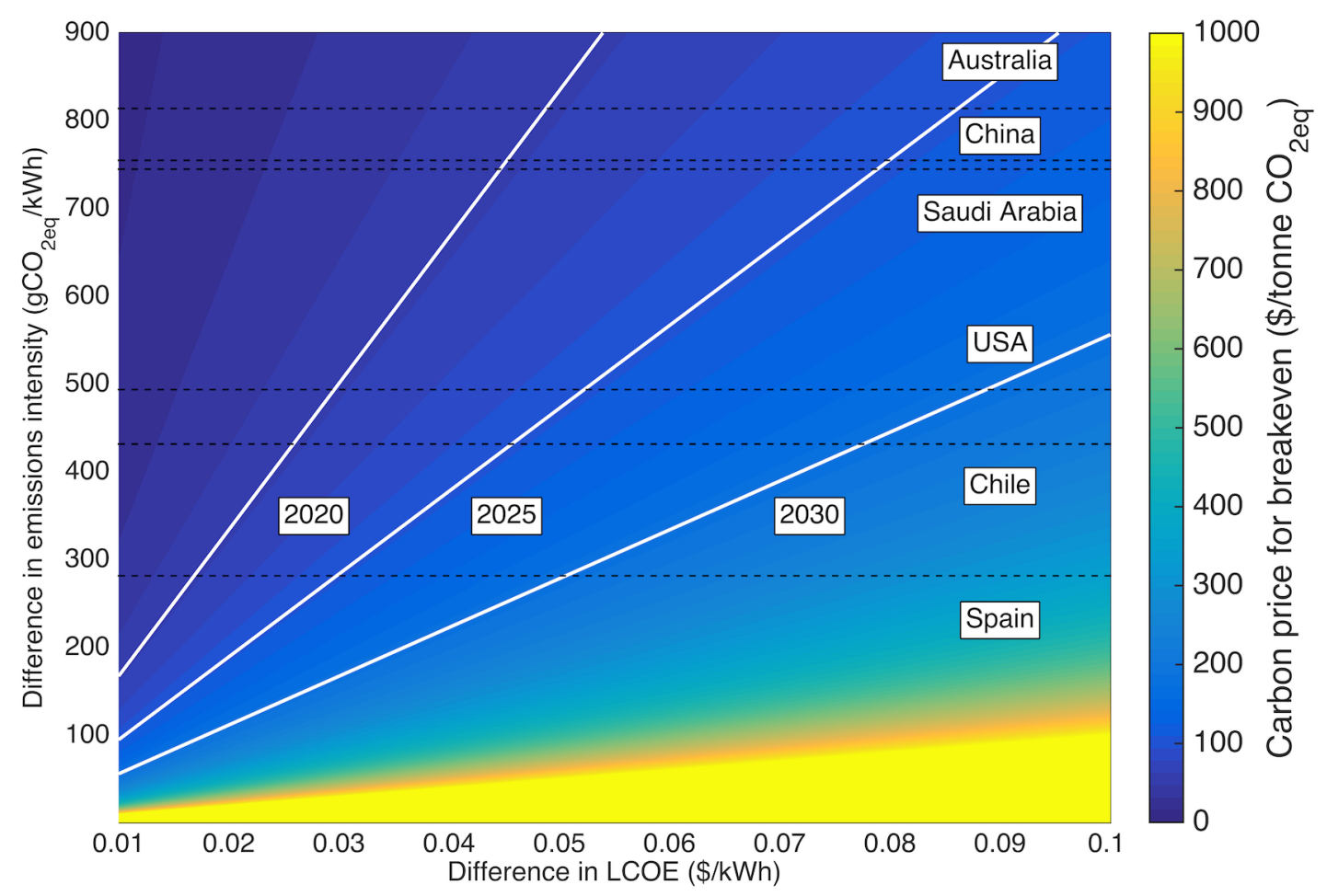

Figure 8 The carbon price required for the LCOE of a lower-emission, higher-cost technology to breakeven against that of a higher-emission, lower cost alternative. Dashed black lines denote the difference between the local grid and Fullsun HCPV systems deployed in the stated country, whilst solid white lines indicate expected carbon prices in the future.

\section{Conclusions}


An LCA of a new design of compact, lightweight HCPV module has been performed to assess the impact of the energy used and greenhouse gases emitted during construction and deployment. The lightweight design uses an advanced optical design to reduce the dimensions of the structure, resulting in a module mass of $4.20 \mathrm{~kg}$ for an output of $83 \mathrm{~W}_{\mathrm{p}}$ under $625 \mathrm{x}$ concentration. The module structural components, namely the glass lens matrix and metal walls and backplane, comprise the largest parts of the CED and embodied GHGs, $355.3 \mathrm{MJ}$ and $27.9 \mathrm{~kg}$ respectively. The relatively low materials usage leads this module to compare very favourably to other reported HCPV designs, with a normalised CED of 4.3 MJ/ $\mathrm{W}_{\mathrm{p}}$, compared to 5.8-12.9 $\mathrm{MJ} / \mathrm{W}_{\mathrm{p}}$ for others.

Six locations suitable for CPV installation are chosen to analyse the impact of the modules over the lifetime of a system. After incorporating transport, maintenance and disposal the EPBTs were calculated to be as low as 0.22 years and, when compared with the local grid GHG intensity, the CPBT was found to be as low as 0.29 years. Specific emissions over the lifetime of the systems were calculated to be $6.5-9.8 \mathrm{gCO}_{2 \mathrm{eq}} / \mathrm{kWh}$.

A simple normalisation process was used to compare the specific emissions of a system using Fullsun modules to those from harmonised LCA studies of other renewable energy sources, with the discussed system having a lower environmental impact than those of other PV, HCPV and concentrated solar power technologies when considered in the same location. The LCOE of the HCPV system is also found to be comparable to more mature technologies for projected 2020 prices, and becomes increasingly cost-effective compared to grid electricity as carbon prices are expected to increase. This suggests that lightweight HCPV module designs could provide cheap, low-carbon electricity in many high irradiance locations in the future.

\section{Acknowledgements}

The authors would like to acknowledge the EPSRC SUPERGEN SuperSolar for grant number EP/J017361 and to thank Ajay Gambhir for his comments on the manuscript. PS would like to thank the Grantham Institute - Climate Change and the Environment and Climate KIC for a PhD scholarship. JN would like to acknowledge the Royal Society for a Wolfson Merit Award. 


\section{Bibliography}

1. ISE, F., Photovoltaics Report. 2014, Fraunhofer ISE.

2. NREL, Best Research-Cell Efficiencies. 2015.

3. Philipps, S.P., et al., Current Status of Concentrator Photovoltaic (CPV) Technology. 2015, Fraunhofer ISE and National Renewable Energy Laboratory.

4. Kost, C., et al., Levelized Cost of Electricity: Renewable Energy Technologies. 2013, Fraunhofer Institute for Solar Energy Systems ISE.

5. Haysom, J.E., et al., Learning curve analysis of concentrated photovoltaic systems. Prog. Photovolt: Res. Appl., 2014.

6. Hsu, D.D., et al., Life Cycle Greenhouse Gas Emissions of Crystalline Silicon Photovoltaic Electricity Generation. Journal of Industrial Ecology, 2012. 16: p. S122-S135.

7. Kim, H.C., et al., Life Cycle Greenhouse Gas Emissions of Thin-film Photovoltaic Electricity Generation. Journal of Industrial Ecology, 2012. 16: p. S110-S121.

8. de Wild-Scholten, M.J., Energy payback time and carbon footprint of commercial photovoltaic systems. Solar Energy Materials and Solar Cells, 2013. 119: p. 296-305.

9. Peharz, G. and F. Dimroth, Energy payback time of the highconcentration PV system FLATCON (R). Progress in Photovoltaics, 2005. 13(7): p. 627-634.

10. de Wild-Scholten, M., et al. Environmental Sustainability of Concentrator PV Systems: Preliminary LCA Results of the APOLLON Project. in 25th European Photovoltaic Solar Energy Conference and Exhibition. 2010. Valencia, Spain.

11. Der Minassians, A., et al., Energy Payback Time of a SolFocus Gen1 Concentrator PV System, in MSE-ER C226 - Photovoltaic Materials. 2006, University of California, Berkeley.

12. Fthenakis, V.M. and H.C. Kim, Life cycle assessment of highconcentration photovoltaic systems. Progress in Photovoltaics, 2013. 21(3): p. 379-388.

13. Timò, G., Results of the APOLLON Project and Concentrating Photovoltaic Perspective. 2014, RSE: Milan, Italy.

14. Fthenakis, V.M. and H.C. Kim, Photovoltaics: Life-cycle analyses. Solar Energy, 2011. 85(8): p. 1609-1628.

15. Fthenakis, V., et al., Methodology Guidelines on Life-Cycle Assessment of Photovoltaic Electricity. 2011, IEA PVPS Task 12, International Energy Agency Photovoltaic Power Systems Programme.

16. Forster, P., et al., Changes in Atmospheric Constituents and in Radiative Forcing. In: Climate Change 2007: The Physical Science Basis. Contribution of Working Group I to the Fourth Assessment Report of the Intergovernmental Panel on Climate Change [Solomon, S., D. Qin, M. Manning, Z. Chen, M. Marquis, K.B. Averyt, M.Tignor 
and H.L. Miller (eds.)]. 2007, Cambridge University Press, Cambridge, United Kingdom and New York, NY, USA.

17. Ito, M., et al., A comparative study on cost and life-cycle analysis for $100 \mathrm{MW}$ very large-scale PV (VLS-PV) systems in deserts using $\mathrm{m}$-Si, a-Si, CdTe, and CIS modules. Progress in Photovoltaics, 2008. 16(1): p. 17-30.

18. Chaurey, A. and T.C. Kandpal, A techno-economic comparison of rural electrification based on solar home systems and PV microgrids. Energy Policy, 2010. 38(6): p. 3118-3129.

19. Durlinger, B., A. Reinders, and M. Toxopeus, A comparative life cycle analysis of low power PV lighting products for rural areas in South East Asia. Renewable Energy, 2012. 41: p. 96-104.

20. Gerbinet, S., S. Belboom, and A. Leonard, Life Cycle Analysis (LCA) of photovoltaic panels: A review. Renewable \& Sustainable Energy Reviews, 2014. 38: p. 747-753.

21. Peng, J.Q., L. Lu, and H.X. Yang, Review on life cycle assessment of energy payback and greenhouse gas emission of solar photovoltaic systems. Renewable \& Sustainable Energy Reviews, 2013. 19: p. 255274.

22. Sinha, P., et al. Eco-Efficiency of CdTe Photovoltaics with Tracking Systems. in 39th IEEE Photovoltaic Specialists Conference (PVSC). 2013. Tampa, FL: leee.

23. Stylos, N. and C. Koroneos, Carbon footprint of polycrystalline photovoltaic systems. Journal of Cleaner Production, 2014. 64: p. 639645.

24. Phillips, S.P., et al., Current Status of Concentrator Photovoltaic (CPV) Technology. 2015, Fraunhofer ISE \& National Renewable Energy Laboratory.

25. Kim, H.C., V.M. Fthenakis, and leee, Life cycle energy demand and greenhouse gas emissions from an Amonix high concentrator photovoltaic system. Conference Record of the 2006 IEEE 4th World Conference on Photovoltaic Energy Conversion, Vols 1 and 2, 2006: p. 628-631.

26. Kim, H.C., et al., Life cycle analysis of two new concentrator PV systems, in 23rd European Photovoltaic Solar Energy Conference and Exhibition. 2008: Valencia, Spain.

27. Kammen, D., et al., An Assessment of the Environmental Impacts of Concentrator Photovoltaics and Modeling of Concentrator Photovoltaic Deployment Using the SWITCH Model. 2011, Renewable and Appropriate Energy Laboratory, University of California Berkeley.

28. Hashimoto, J., et al. Field Experience And Performance Of CPV System In Different Climates. in 9th International Conference on Concentrator Photovoltaic Systems (CPV). 2013. Miyazaki, JAPAN: Amer Inst Physics.

29. Nomura, K., et al., Seasonal variation of performance in concentrator photovoltaic system. Physica Status Solidi C: Current Topics in Solid State Physics, Vol 11, No 9-10, 2014. 11(9-10): p. 1427-1430. 
30. Duggan, G., Concentrated photovoltaic (cpv) cell arrangement, module and method of fabrication. 2014, Fullsun Photovoltaics Limited.

31. Dimroth, F. New world record for solar cell efficiency at $46 \%$. FrenchGerman cooperation confirms competitive advantage of European photovoltaic industry 20141 December 2014 [cited 20145 June 2015].

32. Hammond, G. and C. Jones, Inventory of Carbon and Energy (ICE), U.o. Bath, Editor. 2011.

33. Syrrakou, E., S. Papaefthimiou, and P. Yianoulis, Environmental assessment of electrochromic glazing production. Solar Energy Materials and Solar Cells, 2005. 85(2): p. 205-240.

34. 1 CORE COPPER PVC UNARMOURED POWER CABLES. 4 April 2015]; Available from: http://www.gridcables.com/pdfs/1-core-cuunarmd.pdf.

35. Tutorial - How to apply and cure silicone coatings. 2004, Dow Corning Corporation.

36. Genlab General Purpose Ovens Power Ratings. Available from: http://www.genlab.co.uk/uploads/pdfs/General Purpose Ovens Power Rating.pdf.

37. The Effect on Energy Use from an Optimized Reflow Oven Recipe in Lead-Free Applications. KIC Thermal.

38. Automatic Pick and Place Machines QM2000. [cited 20152 April]; Available from: http://www.smtmax.com/detail.php?id=67.

39. 8000i WIRE BONDER / BALL (STUD) BUMPER. Palomar Technologies.

40. IEA, $\mathrm{CO}_{2}$ Emissions from Fuel Combustion Highlights. 2013.

41. LP, S. Transit Time, Distance Calculator \& Port to Port Distances. 2015 [cited 201510 March 2015]; Available from:

http://www.searates.com/reference/portdistance/.

42. IEA, Transport, Energy and $\mathrm{CO}_{2}$ : Moving Towards Sustainability. 2009, IEA/OECD.

43. Böhmann, A.C., et al., Relevance of infrastructure and ITS, vehicle and engine and logistics technologies on long distance freight transport in Europe 2009: Vienna, Austria.

44. Hoffman, J., et al., Review of Maritime Transport 2014, UNCTAD, Editor. 2014, United Nations.

45. Stackhouse, P.W. and J.M. Kusterer, NASA Surface meteorology and Solar Energy - Location, N.A.S.D. Center, Editor. 2015.

46. Bank, W., Electric power transmission and distribution losses (\% of output). 2014, The World Bank.

47. Savanna ${ }^{T M}$ Dual-Axis PV Tracker Specifications. 2014, Morgan Solar Inc.

48. Nishimura, A., et al., Life cycle assessment and evaluation of energy payback time on high-concentration photovoltaic power generation system. Applied Energy, 2010. 87(9): p. 2797-2807.

49. Staudinger, J. and G.A. Keoleian, Management of End-of-Life Vehicles (ELVs) in the US. 2001, Center for Sustainable Systems, University of Michigan. 
50. Moomaw, W., et al., Annex II: Methodology. In IPCC Special Report on Renewable Energy Sources and Climate Change Mitigation [O. Edenhofer, R. Pichs-Madruga, Y. Sokona, K. Seyboth, P. Matschoss, S. Kadner, T. Zwickel, P. Eickemeier, G. Hansen, S. Schlömer, C. von Stechow (eds)]. 2011: Cambridge, United KingdomNew York, NY, USA.

51. SunShot Vision Study, U.S.D.o. Energy, Editor. 2012.

52. Updated short-term traded carbon values used for UK public policy appraisal. 2014, Department of Energy \& Climate Change.

53. Emmott, C.J.M., N.J. Ekins-Daukes, and J. Nelson, Dynamic carbon mitigation analysis: the role of thin-film photovoltaics. Energy \& Environmental Science, 2014. 7(6): p. 1810-1818. 